\title{
DRINKING TO STOP WATCHING THE CLOCK: PHYSICAL DISTANCING, STRESS

\author{
AND ALCOHOL CONSUMPTION DURING \\ THE COVID-19 OUTBREAK
}

PICIE DLA ZABICIA CZASU: DYSTANS FIZYCZNY, STRES I SPOŻYCIE ALKOHOLU PODCZAS EPIDEMII COVID-19

\author{
Bishwajit Ghose $^{1} \mathbb{D}$, Jude Mary Cénat ${ }^{2} \mathbb{D}$ \\ ${ }^{1}$ Children's Hospital of Eastern Ontario Research Institute, Ottawa, Canada \\ ${ }^{2}$ School of Psychology, Faculty of Social Sciences, University of Ottawa, Canada
}

Alcohol Drug Addict 2020; 33 (2): 199-202 DOI: https://doi.org/10.5114/ain.2020.98881

\begin{abstract}
The novel coronavirus (COVID-19), with its complex and unique pathophysiology, is an emerging threat for global health and is affecting the health and social wellbeing of the population in unprecedented ways, one of the most noticeable of which is skyrocketing sales of alcoholic beverages. Increased alcohol drinking is strongly correlated with weak immune system and heightened risk of pulmonary infections. Increased level of drinking to cope with the stress resulting from disruption in daily living can further increase the susceptibility to COVID-19 related morbidity and mortality, and delay recovery. Countermeasures against controlling the virus, such as physical distancing, should therefore be accompanied by those on limiting sales and consumption of alcohol as well. In order to prevent
\end{abstract}

\begin{abstract}
Streszczenie
Nowy koronawirus (COVID-19), ze względu na złożoną i unikalną patofizjologię, stanowi zagrożenie dla zdrowia na świecie i ma duży wpływ na zdrowie i dobrostan społeczny ludności. Jeden z najbardziej zauważalnych jego efektów to gwałtowny wzrost sprzedaży napojów alkoholowych. Zwiększona konsumpcja alkoholu jest silnie związana $\mathrm{z}$ osłabieniem układu odpornościowego i ryzykiem infekcji płuc. Nadmierne picie alkoholu w celu radzenia sobie ze stresem i trudnościami wynikającymi z życia $\mathrm{w}$ pandemii może dodatkowo zwiększać związaną z COVID-19 podatność na choroby i śmiertelność, a przynajmniej opóźniać powrót do zdrowia. Dlatego też środkom zapobiegającym rozprzestrzenianiu się wirusa, takim jak dystans fizyczny, powinny towarzyszyć środki ograniczające sprzedaż i spożycie alkoholu. Trzeba zapobiegać nadmiernej konsumpcji oraz
\end{abstract}

Correspondence to/Adres do korespondencji: Bishwajit Ghose, Children's Hospital of Eastern Ontario Research Institute, 401 Smyth Road, Ottawa, Ontario K1H 8L1, Canada, e-mail: brammaputram@gmail.com

Authors' contribution/Wkład pracy autorów: Study design/Koncepcja badania: B. Ghose, J.M. Cénat; Data interpretation/Interpretacja danych: B. Ghose; Literature search/Przygotowanie literatury: B. Ghose, J.M. Cénat

No ghostwriting and guest authorship declared./Nie występują zjawiska ghostwriting i guest authorship.

Submitted/Otrzymano: 27.07.2020 • Accepted/Przyjęto do druku: 30.07.2020

(c) 2020 Institute of Psychiatry and Neurology. Production and hosting by Termedia sp. z o.o.

This is an open access article under the CC BY-NC-ND license (http://creativecommons.org/licenses/by-nc-nd/4.0/) 
the risk of overconsumption during the pandemic, and minimise the risk for post-pandemic increase in alcohol use disorders and associated mental health issues, public health services and programmes should pay special attention to the underlying factors and take evidence-based measures to address them.

Keywords: Alcohol drinking, COVID-19, Psychosocial stress. minimalizować ryzyko popandemicznego wzrostu zaburzeń związanych z używaniem alkoholu i towarzyszących im problemów ze zdrowiem psychicznym. W tym celu publiczna służba zdrowia powinna zwracać szczególną uwagę na czynniki leżące u podstaw tych problemów i przeciwdziałać im przez podejmowanie działań opartych na dowodach naukowych.

Słowa kluczowe: konsumpcja alkoholu, COVID-19, stres psychospołeczny.

\section{- INTRODUCTION}

On January 30, 2020, World Health Organization declared the novel coronavirus (COVID-19) outbreak as a Public Health Emergency of International Concern (PHEIC). Countries around the world have soon responded to the emergency through adoption of various strategies to contain the outbreak such as cessation of local and international travels, foreclosure of non-essential businesses, home quarantine for at-risk population and strict physical distancing. Maintaining physical isolation to curb the epidemic is of paramount importance. However, the current situation is quite unique for nearly all people who are alive today. What this means is that people are not only immune to the virus, but are also foreign to the rapid transformations in daily living conditions that are being applied to tackle the pandemic [1]. The drastic alterations in social and personal aspects of living can trigger severe psychosocial stress, adjusting to which can be overwhelming and come at the cost of risky behavioural modifications such as immoderate alcohol consumption [2].

The temporary relaxing effect of alcohol drinking and its wide availability make it a popular choice for wading through the periods of stress and boredom that are being caused by chronic physical distancing. Periodic social isolation under normal circumstances is not uncommon; however, having to avoid in-person communication during times when mutual caregiving and sharing are most needed can be extremely challenging for individual's psychological wellbeing. Inability to adjust with the stress can encourage light to moderate drinking for new, and more frequent or voluminous drinking for existing consumers. Emotional hardship and loneliness are compelling issues of our time, and to make things worse, use of alcohol and other mood-altering substances are becoming highly sought-after coping strategies [3]. The social isolation imposed by COVID-19, the uncertainty of the pandemic period, the death of loved ones, loss of income and financial problems represent considerable risk factors for alcohol and substance use. Most recently, as travel bans likely to have halted the supply of illicit drugs, addicts are some of the hardest hit population by the COVID-19 crisis and are being forced to look for affordable alternatives. As such, the dramatic rise in alcohol sales can be attributed to a great extent to the heavy demand for an alternative of drugs that went to short supply, as well as to growing unmet need for an emotional refugee for the isolation-ridden individuals.

\section{- How ThE COVID-19 PANDEMIC IS POTENTIALLY FUELING EXCESSIVE DRINKING}

The COVID-19 situation is rare and is presenting a unique set of psychosocial challenges for people of all ages and walks of life. However, people from certain backgrounds are at increased risk of stress and problematic drinking. For instance, those involved in caregiving profession, especially frontline health workers such as doctors and nurses who are undergoing long restless weeks are also at risk of over drinking. Problematic alcohol use to cope with occupational burn out is well-known among clinicians [4] as well as among informal caregivers [5]. Given the added physical exhaustion and fear of getting infected, the ongoing pandemic can greatly fuel emotional drinking particularly among newly-appointed health professionals. Indeed, the large number of deaths, the overflow 
of services, the feeling of powerlessness, the fear of being infected and of infecting family members, the physical and emotional fatigue, and the exacerbation of conflicts among staff put health professionals at even greater risk of over drinking.

Owing to shortage of hospital staffs due to COVID-19 outbreak, many clinicians are ending up doing additional tasks and facing significantly higher workloads amid stressful working conditions.

On the care-receiver side, the situation is more unique for many communities across Asia and Africa where alcohol is considered ritually impure both for recreation and cosmetic purposes e.g. perfumery. Among those unaccustomed to the application of commercial alcohol-based sanitisers, the newfound knowledge about alcohol's antiseptic efficacy are sometimes being misconstrued as its having in-vivo virucidal capacities. Misinterpretation of research findings regarding the antiviral properties of certain alcoholic compounds (such as combined monoterpene alcohols against West Nile virus) [6] and higher susceptibility of COVID-19 to alcohol-based sanitisers than SARS-CoV and MERS-CoV [7] are likely to be contributing to the spread of such misinformation. The brewing misconception regarding various antiviral and immune-boosting effects of alcohol is provoking not only the consumption of alcoholic beverages, but also of the more toxic types (methanol) where alcohol drinking is criminalised and commercially unavailable [8].

Several other factors that can induce over drinking during the prolonged self-confinement include not having to attend work in person and little or no need for driving. Under usual living conditions, the leisure for consuming alcohol is generally more limited as a greater chunk of time is spent on attention-demanding occupations and in places where drinking is against the norm. The extending lockdown, in contrast, is reducing the necessity for maintaining a strict drinking routine, which can translate to a vacation-like indulgence with lesser demand for self-control. Even for light or social drinkers, alcohol can serve as an easily applicable self-medication strategy to endure the ever-stretching hours of seclusion. Filling the empty time-slots can be equally onerous for those who have been practicing abstinence or recovering from alcohol use disorders (AUD). In addition, watching the sales of alcohol skyrock- eting, and fantasising on drinking while undergoing the trials of pervasive panic and isolation can greatly enhance the risk of relapse as well. Not being able to attend counselling sessions or meet up with support groups can also impede recovery and thereby facilitate stepping into another cycle of addiction.

\section{- CONCLUSION AND RECOMMENDATIONS}

Oversight of the effects of increased alcohol consumption during the pandemic can have serious implications for effective containment and treatment of the disease. In terms of the risk of COVID-19 related fatality and morbidity, both acute and chronic alcohol drinking can be exceptionally harmful due to the adverse effects on alveolar environment (potential site for COVID-19 attack) [9], such as through production of pulmonary toxin and damage of alveolar type- 2 cells [10]. In countries where drinking is customary, controlling excessive alcohol consumption should therefore be regarded as an important component of controlling the pandemic. Special attention should also be paid to those suffering from alcohol-dependence as well as the recovering patients owing to impaired immune system. Arguably, surge in demand for alcohol is one of the most important public health side-effects of the COVID-19 outbreak. As the healthcare systems are already overstrained in dealing with the epidemic, the resultant spike in AUD and other alcohol-induced physical and psychological disorders may soon pose serious constraints on the limited resources that can not only hamper fighting against the virus, but also delay the process of post-epidemic recovery and resilience building. Strategies to curb the virus, such as physical and social distancing, should therefore be accompanied by those on limiting sales and consumption of alcohol as well.

In order to prevent the risk of overconsumption, mental health programmes should pay more attention to this aspect. When people call the crisis lines, chat with psychological counsellors, attend tele-psychology sessions, mental health professionals should always investigate over drinking and address it. Public health services should also develop campaigns to prevent over drinking in the population. Community organisations could also organise online cultural activities based on 
a community empathy approach designed to break social isolation. At the end of the confinement and physical distancing measures and the pandemic of COVID-19, these actions should prevent an epidemic situation of alcohol abuse and the resultant physical and psychosocial outcomes.

\section{Conflict of interest/Konflikt interesów}

None declared./Nie występuje.

\section{Financial support/Finansowanie}

None declared./Nie zadeklarowano.

\section{Ethics/Etyka}

The work described in this article has been carried out in accordance with the Code of Ethics of the World Medical Association (Declaration of Helsinki) on medical research involving human subjects, Uniform Requirements for manuscripts submitted to biomedical journals and the ethical principles defined in the Farmington Consensus of 1997.

Treści przedstawione w pracy są zgodne z zasadami Deklaracji Helsińskiej odnoszącymi się do badań z udziałem ludzi, ujednoliconymi wymaganiami dla czasopism biomedycznych oraz z zasadami etycznymi określonymi w Porozumieniu z Farmington w 1997 roku.

\section{References/Piśmiennictwo}

1. Abel T, McQueen D. The COVID-19 pandemic calls for spatial distancing and social closeness: not for social distancing! Int J Public Health 2020; 1.

2. Keyes KM, Hatzenbuehler ML, Hasin DS. Stressful life experiences, alcohol consumption, and alcohol use disorders: the epidemiologic evidence for four main types of stressors. Psychopharmacology (Berl) 2011; 218: 1-17.

3. McKay MT, Konowalczyk S, Andretta JR, Cole JC. The direct and indirect effect of loneliness on the development of adolescent alcohol use in the United Kingdom. Addict Behav Rep 2017; 6: 65-70.

4. Oreskovich MR, Shanafelt T, Dyrbye LN, Tan L, Sotile W, Satele D, et al. The prevalence of substance use disorders in American physicians. Am J Addict 2015; 24: 30-8.

5. Rospenda KM, Minich LM, Milner LA, Richman JA. Caregiver Burden and Alcohol Use in a Community Sample. J Addict Dis 2010; 29: 314-24.

6. Pliego Zamora A, Edmonds JH, Reynolds MJ, Khromykh AA, Ralph SJ. The in vitro and in vivo antiviral properties of combined monoterpene alcohols against West Nile virus infection. Virology 2016; 495: 18-32.

7. Kampf G, Todt D, Pfaender S, Steinmann E. Persistence of coronaviruses on inanimate surfaces and their inactivation with biocidal agents. J Hosp Infect 2020; 104: 246-51.

8. Iranpour P, Firoozi H, Haseli S. Methanol Poisoning Emerging as the Result of COVID-19 Outbreak; Radiologic Perspective. Acad Radiol 2020. DOI: 10.1016/j.acra.2020.03.029.

9. Tian S, Xiong Y, Liu H, Niu L, Guo J, Liao M, et al. Pathological study of the 2019 novel coronavirus disease (COVID-19) through postmortem core biopsies. Modern Pathol 2020; 33: 1007-14.

10. Mason RJ. Pathogenesis of COVID-19 from a cell biologic perspective. Eur Respir $J$ 2020. DOI: $10.1183 / 13993003.00607-2020$. 